\title{
Synthesis of Multifunctionalised 2-Substituted Benzimidazoles Using Copper (II) Hydroxide as Efficient Solid Catalyst
}

\author{
Murugulla Adharvana Chari ${ }^{{ }^{*}}$, Zaied-A-Mosaa ${ }^{1,2,3}$, Donthabakthuni Shobha ${ }^{1}$, Sridhar Malayalama ${ }^{1}$ \\ ${ }^{1}$ Dr. MACS Bio-Pharma Pvt. Ltd., Pashamylaram, Patancheru, Hyderabad, India \\ ${ }^{2}$ Center for Chemical Science \& Technology, Institute of Science \& Technology, \\ Jawaharlal Nehru Technological University, Hyderabad, India \\ ${ }^{3}$ College of Science for Women, Babylon University, Babylon, Iraq \\ Email:*drmac_s@yahoo.com
}

Received October 1, 2013; revised November 5, 2013; accepted November 21, 2013

Copyright (C) 2013 Murugulla Adharvana Chari et al. This is an open access article distributed under the Creative Commons Attribution License, which permits unrestricted use, distribution, and reproduction in any medium, provided the original work is properly cited.

\begin{abstract}
Here we demonstrate the synthesis of multifunctionalised benzimidazoles through the coupling of $o$-phenylenediamine with aldehydes by using Copper (II) hydroxide as an efficient solid catalyst in methanol at room temperature. The Copper (II) hydroxide solid catalyst gave better yields $(80 \%-99 \%)$ in short reaction time $(4-8 \mathrm{~h})$. These commercially available cheap catalysts are more active than many reported expensive heterogeneous catalysts. Using the Copper hydroxide fresh catalyst, the yield of product 3a was $98 \%$, while the recovered catalyst in the three subsequent cycles gave the yield of $94 \%, 90 \%$ and $88 \%$ respectively.
\end{abstract}

Keywords: $o$-Phenylenediamine; Aldehydes; Copper (II) Hydroxide; Solid Catalyst; Multifunctionalised Benzimidazoles

\section{Introduction}

Among the various nitrogen containing heterocycles, benzimidazole derivatives exhibit antiviral, antiulcer, antihypertensive and anticancer properties [1-4]. The benzimidazoles are biologically potent [5-7] and this moiety is an important pharmacophore $[8,9]$ in drug discovery and also a good intermediate $[10,11]$ for synthesis of many important organic compounds. Generally, the synthesis of 2-substituted benzimidazoles involves the treatment of $o$-phenylenediamines with either carboxylic acids [12-16] or their derivatives (nitriles, imidates or orthoesters) [17-19], under strongly acidic conditions and sometimes combines with very high temperatures (i.e., PPA, $180^{\circ} \mathrm{C}$ ) or the use of microwave irradiation [20-22]. These derivatives also often generated from the condensation of $o$-phenylenediamines with aldehydes $[23,24]$ under oxidative conditions [25-31] using various oxidative and catalytic reagents [32,33] such as nitrobenzene (high-boiling point oxidant/solvent) [32,33], 1,4-benzoquinone, $\mathrm{PhI}(\mathrm{OAc})_{2}, \mathrm{Zn}$-proline, heteropoly acids, thionyl

"Corresponding author. chloride-treatment, 2,3-dichloro-5,6-dicyanobenzoquinone (DDQ), electron-deficient olefins, benzofuroxan, $\mathrm{MnO}_{2}$, $\mathrm{Pb}(\mathrm{OAc})_{4}$ [26], oxone, $\mathrm{NaHSO}_{3}, \mathrm{H}_{2} \mathrm{O}_{2} / \mathrm{HCl}$, Iodine \& hypervalent iodine (iodobenzene diacetate (IBD), $\mathrm{Na}_{2} \mathrm{~S}_{2} \mathrm{O}_{5}$, air, sulfamic acid, $\mathrm{FeCl}_{3} \cdot 6 \mathrm{H}_{2} \mathrm{O}, \operatorname{In}(\mathrm{OTf})_{3}, \mathrm{Yb}(\mathrm{OTf})_{3}$, $\mathrm{Sc}(\mathrm{OTf})_{3}, \mathrm{Cu}(\mathrm{OTf})_{2}, \mathrm{KHSO}_{4}$, IL, (bromo dimethyl) sulfoniumbromide, p-TSA, $\mathrm{ZrOCl}_{2} \cdot 8 \mathrm{H}_{2} \mathrm{O}, \mathrm{ZrCl}_{4}, \mathrm{HfCl}_{4}$, borontrifluoride etherate, copper complex, polyaniline salt, Heuland natural zeolite, NaYzeolite, polymer-supported hypervalent iodine, TsOH/graphite and $\mathrm{N}, \mathrm{N}$-dimethyl aniline/graphite, cobalt(III) salen complex on activated carbon, cobalt(II) chloride hexahydrate, $\mathrm{VO}(\mathrm{acac})_{2}$ $\mathrm{CeCl}_{3}$ combo catalyst, gold/CeO 2 , AlKIT-5 copper iodide catalysts have been employed as the reagents or catalysts $[32,33]$ for the synthesis of benzimidazoles. Although the reaction was efficiently promoted by the above conditions, they are often homogeneous catalysts and some of these methods suffer from one or more disadvantages such as usage of stoichiometric or more quantity of reagent, high cost of the catalysts, prolonged reaction times, occurrence of several side reactions, severe reaction conditions, difficulty in separation of the 
products from the reaction mixture and strong oxidizing nature of the reagents. Therefore, the discovery of mild and practicable, stable, cheap, recyclable, and ecofriendly heterogeneous catalysts for synthesis of 2-substituted benzimidazoles continues to attract the attention of researchers.

Recently the uses of heterogeneous catalysts [34-45] including zeolites [32,33,36-42] and nanoporous materials [43-45] have been received considerable importance in organic synthesis because of their ease of handling, enhanced reaction rates, greater selectivity, and simple workup. Since we have published the preparation of nanocrystals of cobalt oxides and hydroxides [46], we have sought the application as catalysts for organic reactions. Along this process, we have found that $\mathrm{Cu}(\mathrm{OH})_{2}$ s which are as purchased solid catalysts exhibit catalytic activity for benzimidazole derivative synthesis. These solid catalysts are commercially available, non-hazardous, clean, cost-effective compared with other heterogeneous catalysts. In the continuation of our interest on catalytic applications of various heterogeneous catalysts, herein we report for the first time a simple, convenient and efficient method for the synthesis of multi-functionalised benzimidazole and its derivatives using $\mathrm{Cu}(\mathrm{OH})_{2}$ as a reusable solid catalyst. Copper (II) hydroxide is a pale blue, gelatinous solid and rarely found as an uncombined mineral, because it slowly reacts at room temperature in methanol using $\mathrm{Cu}(\mathrm{OH})_{2} \mathrm{~s}$ as reusable solid catalysts. However, to the best of our knowledge, there has been no report available on the synthesis of multi-functionalised benzimidazoles using $\mathrm{Cu}(\mathrm{OH})_{2}$ in the open literature so far.

\section{Results and Discussion}

Initially, we have attempted the condensation of $o$-phenylenediamine $1(1.0 \mathrm{mmol})$ with benzaldehyde $2(\mathrm{R}=$ $\mathrm{Ph})(1.2 \mathrm{mmol})$ at room temperature in methanol condition for $6 \mathrm{~h}$ at open oxygen atmosphere, in absence of catalyst by M.A.Chari et al., [32,33] and they have reported $27.6 \%$ of 2-phenyl benzimidazole product 3 and $0.1 \%$ of 1 -benzyl-2-phenyl-1 $H$-benzimidazoleproduct 4 at $6 \mathrm{~h}$ and on long reaction time $(12 \mathrm{~h})$ resulted the formation of a mixtures like 2-phenyl benzimidazole 3 (29.1\%) and 1-benzyl-2-phenyl-1H-benzimidazole 4 (2\%) as side-product. The detailed mechanistic study on oxygen-catalyzed coupling of $o$-phenylenediamine and benzaldehyde was carried out by Smith and Ho [47]. We have performed control experiments in absence of air under $\mathrm{N}_{2}$ atmosphere using $\mathrm{Cu}(\mathrm{OH})_{2}$ catalyst, but the reaction was not proceeding much, these gave very low yields of $3(7 \%, 9 \%, 17 \%)$ at $6 \mathrm{~h}$ at RT to optimise the conditions. This indicates the presence of oxygen is important for the reaction. We have carried out the reaction using different amounts of catalyst (Table 1). It was
Table 1. Effect of the amount and catalytic activity of the various catalysts in the synthesis of multifunctionlised benzimidazoles.

\begin{tabular}{ccccc}
\hline S.No. & Catalyst & $\begin{array}{c}\text { Amount of } \\
\text { catalyst (mol\%) }\end{array}$ & Time & Yield (\%) \\
\hline 1 & No catalyst & - & $6 \mathrm{~h}$ & $27.63 \%, 0.1$ ref. [33] \\
2 & $\mathrm{Co}_{3} \mathrm{O}_{4}(\mathrm{II}, \mathrm{III})$ & 10 & $6 \mathrm{~h}$ & $78.9 \%$ ref. [33] \\
3 & $\mathrm{CoO}(\mathrm{II})$ & 10 & $6 \mathrm{~h}$ & $93 \%$ ref. [33] \\
4 & $\mathrm{Co}(\mathrm{OH})_{2}$ & 10 & $4 \mathrm{~h}$ & $96.4 \%$ ref. [33] \\
5 & $\mathrm{Cu}(\mathrm{OH})_{2}$ & 2 & $4 \mathrm{~h}$ & 77 \\
6 & $\mathrm{Cu}(\mathrm{OH})_{2}$ & 5 & $4 \mathrm{~h}$ & 87 \\
7 & $\mathrm{Cu}(\mathrm{OH})_{2}$ & $\mathbf{1 0}$ & $4 \mathrm{~h}$ & $\mathbf{9 8}$ \\
8 & $\mathrm{Cu}(\mathrm{OH})_{2}$ & 15 & $4 \mathrm{~h}$ & 98 \\
\hline
\end{tabular}

Reaction Conditions: substrates: $o$-phenylenediamine $(108 \mathrm{mg}, 1.0 \mathrm{mmol}$ ), benzaldehyde (127 mg, $1.2 \mathrm{mmol}$ ), amount of catalyst $=10 \mathrm{mg}, 10 \mathrm{~mol} \%$, reaction was conducted at room temperature in methanol as solvent.

observed that the amount of catalyst plays a significant role in controlling the activity of the catalyst. Among the various amounts of catalyst studied, $2 \mathrm{~mol} \%, 5 \mathrm{~mol} \%, 10$ $\mathrm{mol} \%$ and $15 \mathrm{~mol} \%$ of $\mathrm{Cu}(\mathrm{OH})_{2}$ catalyst and $10 \mathrm{~mol} \%$ of catalyst was found to be the best at room temperature in methanol condition and 2-phenyl-1H-benzimidazole 3 was isolated in high yield within short time (Scheme 1, Table 1).

In the case of $\mathrm{Cu}(\mathrm{OH})_{2}$ catalyst, the yields of the final product increases from $77 \%$ to $98 \%$ and whereas in the case of $\mathrm{CoO}$ (II) catalyst [33], the product yield increases from $72 \%$ to $93 \%$ with increasing the catalyst weight from $2 \mathrm{~mol} \%$ to $10 \mathrm{~mol} \%$. The literature survey reveals that the $10 \mathrm{~mol} \% \mathrm{Co}_{3} \mathrm{O}_{4}$ (II, III) activity [33] on this synthesis, gave yield $79 \%$ was lower than that by $\mathrm{Co}(\mathrm{OH})_{2}$ and $\mathrm{CoO}$ (II) solid catalysts. The order of activity was found as $\mathrm{Cu}(\mathrm{OH})_{2}>\mathrm{Co}(\mathrm{OH})_{2}>\mathrm{CoO}(\mathrm{II})>\mathrm{Co}_{3} \mathrm{O}_{4}$. It was found that the present reaction readily proceeds, whereas no simple oxidation of aldehyde was observed.

The effect of the solvents affecting the catalytic activity of the copper hydroxide was also investigated under the optimized reaction conditions. Among various solvents like dichloro methane, methanol, acetonitrile and ethanol used for this transformation, methanol showed the highest yield $(98 \%)$ in $4 \mathrm{~h}$ and was found to be the best solvent. Acetonitrile (94\%) and ethanol (90\%) exhibited almost the same activity and dichloro methane showed poor activity (40\%). As per a plausible mechanism, the reaction proceeds via the activation of aldehyde 2 by $\mathrm{Cu}(\mathrm{OH})_{2}$ followed by imine formation $\mathbf{A}$ and this resulting imine further reacts with another $-\mathrm{NH}_{2}$ group of $o$-phenylenediamine resulting in the formation of dihydroimidazole $\mathbf{B}$ which subsequently undergoes aromati- 


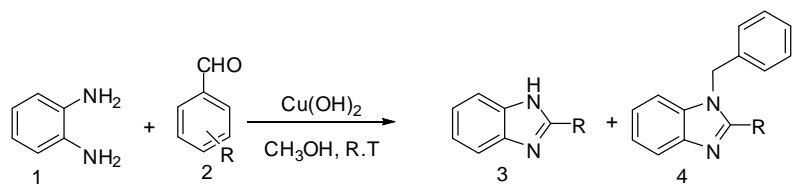

Scheme 1. Room temperature synthesis of multifunctionlised benzimidazoles using copperhydroxide solid catalyst.

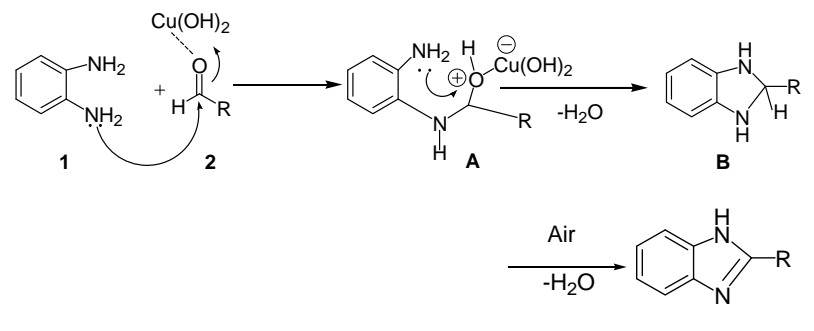

3

Scheme 2. A plausible mechanism for the synthesis of multifunctionalised benzimidazoles using $\mathrm{Cu}(\mathrm{OH})_{2}$.

zation under the oxidative conditions to give the benzimidazole $\mathbf{3}$ as shown in Scheme 2.

Encouraged by these results, we examined several substituted aldehydes including aromatic, heteroaromatic and aliphatic groups, which underwent smooth conversion to afford a wide range of benzimidazoles (Table 2). Aromatic aldehydes containing both electron-donating and electron-withdrawing groups worked well in this reaction. Unfortunately metal hydroxides are not explored much in the synthesis of various benzimidazoles. It was found that transition metal oxide is more effective for oxidation than the corresponding zero-valent metal powders. Open air and copper hydroxide both may be sources for the oxidation process. Here, it seems that copper hydroxide solid catalyst is acting as bifunctional like Lewis acid as well as oxidative reagent.

Many heterogeneous catalysts [32,33] and expensive Co(III) salen complexes [48] were used in the synthesis of various benzimidazoles. But all they have not achieved the products using aliphatic aldehydes. The present catalyst is simple, recyclable, green catalyst and more convenient than many catalysts presented in the above introduction. These catalysts were also found to be very active in the synthesis of benzimidazoles using an acid sensitive furfuraldehyde (3f) and bulky naphthaldehyde (3g), also worked well. Various substituted aldehydes have been used with similar success to provide the corresponding benzimidazoles in high yields $(80 \%-99 \%)$.

Finally, recycling experiments were conducted to find out the stability and reusability of the catalysts after the reaction. The catalyst was easily separated by centrifuge and reused after drying at $100^{\circ} \mathrm{C}$ for $4 \mathrm{~h}$. The efficiency of the recovered catalyst was verified with the Entry a, Table 3. Using the Copper hydroxide fresh catalyst, the yield of product 3a was 98\%, while the recovered catalyst in the three subsequent cycles gave the yield of $94 \%$, $90 \%$ and $88 \%$ respectively (Table 3 ).

In addition we have also carried out scale up experiments with $1.08 \mathrm{~g}$ of $o$-phenylenediamine and $1.27 \mathrm{~g}$ of benzaldehyde using $10 \mathrm{~mol} \%$ of Copper hydroxide catalyst at room temperature in methanol. The $\mathrm{Cu}(\mathrm{OH})_{2}$ catalyst gave $98 \%$ of product $3 \mathbf{3}$, that is almost similar to the yield obtained in Table 2 Entry a, indicating that the catalyst could be easily used on a large scale. In the present work, the catalytic activity of the $\mathrm{Cu}(\mathrm{OH})_{2}$ has been studied for synthesis of multifunctionalised benzimidazole derivatives at room temperature. It has been found that these commercially available catalysts are very cheap, recyclable and showed superior activity at room temperature than $\mathrm{Co}$ (III) salen [48], and cheaper than many other expensive heterogeneous catalysts [32,33]. All the synthesized compounds (3a-3v) colour, melting points were checked and characterized by using IR and ${ }^{1} \mathrm{H}-\mathrm{NMR}$ spectra data was given below.

\section{Conclusion}

In summary, benzimidazole and its derivatives were synthesized by the coupling of $o$-phenylenediamine with various aldehydes using commercially available $\mathrm{Cu}(\mathrm{OH})_{2}$ as an efficient recyclable solid catalyst under open oxygen atmosphere at room temperature using methanol as solvent. Various multifunctionalised Benzimidazoles could successfully be synthesized by using the $\mathrm{Cu}(\mathrm{OH})_{2}$ catalyst with acid sensitive, sterically hindered and substituted aromatic and aliphatic aldehydes. The reactions were performed in methanol and the catalyst could be reused for several cycles without much decrease in activity. The salient features of the present method include mild conditions, short reaction times, high yields, recyclable catalyst, large scale synthesis and simple procedure. These catalysts could replace the existing homogeneous and expensive heterogeneous catalysts which are currently being used in the synthesis of various industrially important and biologically active benzimidazoles.

\section{Experimental Section}

All chemicals and solvents were obtained from Aldrich and Spectrochem Pvt.Ltd., and used without further purification. Column chromatographic separations were carried out on silica gel of 60 - 120 mesh size. Melting points were determined on an open capillary apparatus and are uncorrected. The infrared absorption spectrums were obtained by using Perkin Elmer, Spectrum FTIR spectrophotometer with substances being pressed in a $\mathrm{KBr}$ pellet. The ${ }^{1} \mathrm{H}$ NMR spectra of samples were recorded on a JEOL 400-MHz NMR spectrometer using TMS as an internal standard in DMSO- $d_{6}$. The ${ }^{1} \mathrm{H}$ chemical shift 
Table 2. Synthesis of multifunctionalised 2-substituted benzimidazoles using $\mathrm{Cu}(\mathrm{OH})_{2}$.

\begin{tabular}{|c|c|c|c|c|c|}
\hline entry & Diamine & Aldehyde & Product (3) & Time/h & Yield (\%) \\
\hline $\mathrm{a}$ & & & & 4 & 98 \\
\hline $\mathrm{b}$ & & & & 6 & 95 \\
\hline $\mathrm{c}$ & & & & 4 & 99 \\
\hline d & & & & 6 & 88 \\
\hline $\mathrm{e}$ & & & & 6 & 90 \\
\hline $\mathrm{f}$ & & & & 6 & 86 \\
\hline $\mathrm{g}$ & & & & 6 & 84 \\
\hline $\mathrm{h}$ & & & & 6 & 88 \\
\hline $\mathrm{i}$ & & & & 6 & 88 \\
\hline $\mathrm{j}$ & & & & 6 & 88 \\
\hline $\mathrm{k}$ & & & & 8 & 84 \\
\hline 1 & & & & 8 & 80 \\
\hline $\mathrm{m}$ & & & & 8 & 90 \\
\hline $\mathrm{n}$ & & 0 & & 8 & 93 \\
\hline $\mathrm{o}$ & & - & & 8 & 84 \\
\hline
\end{tabular}


$\mathrm{p}$<smiles>Nc1ccc([N+](=O)[O-])cc1N</smiles>

q<smiles>Nc1ccc([N+](=O)[O-])cc1N</smiles>

r<smiles>Nc1ccc([N+](=O)[O-])cc1N</smiles>

$\mathrm{S}$<smiles>Nc1ccc([N+](=O)[O-])cc1N</smiles><smiles>Nc1ccc([N+](=O)[O-])cc1N</smiles>

u<smiles>Nc1ccc([N+](=O)[O-])cc1N</smiles><smiles>Nc1ccc([N+](=O)[O-])cc1N</smiles><smiles>O=Cc1ccc(O)cc1</smiles><smiles>COc1ccc(C=O)cc1</smiles><smiles>O=Cc1ccco1</smiles><smiles>O=Cc1ccc2ccccc2c1</smiles><smiles>O=Cc1cccc(O)c1</smiles><smiles>O=Cc1ccc(O)cc1O</smiles><smiles>COc1ccc(C=O)cc1OC</smiles><smiles>O=[N+]([O-])c1ccc2[nH]c(-c3ccc(O)cc3)nc2c1</smiles><smiles>COc1ccc(-c2nc3cc([N+](=O)[O-])ccc3[nH]2)cc1</smiles><smiles>O=[N+]([O-])c1ccc2[nH]c(-c3ccco3)nc2c1</smiles><smiles>O=[N+]([O-])c1ccc2[nH]c(-c3cccc4ccccc34)nc2c1</smiles><smiles>O=[N+]([O-])c1ccc2[nH]c(-c3cccc(O)c3)nc2c1</smiles>

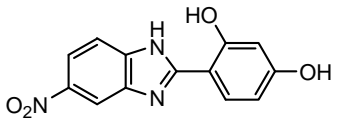<smiles>COc1ccc(-c2nc3cc([N+](=O)[O-])ccc3[nH]2)cc1OC</smiles>

Table 3. Recycle performances in the synthesis of multifunctionalised benzimidazole 3a using Copper hydroxide as recyclable solid catalyst.

\begin{tabular}{cccc}
\hline S.No & Catalyst $(10$ mol\%) & No. of Cycles & Yield (\%) \\
\hline 1 & $\mathrm{Cu}(\mathrm{OH})_{2}$ & Cycle-1 & 98 \\
2 & $\mathrm{Cu}(\mathrm{OH})_{2}$ & Cycle -2 & 94 \\
3 & $\mathrm{Cu}(\mathrm{OH})_{2}$ & Cycle-3 & 90 \\
4 & $\mathrm{Cu}(\mathrm{OH})_{2}$ & Cycle-4 & 88 \\
\hline
\end{tabular}

values were reported on the $\delta$ scale in ppm, relative to TMS and DMSO- $d_{6}$ as solvent. Coupling constants $(J)$ are reported in hertz $(\mathrm{Hz})$.

\section{General Procedure}

To a mixture of $o$-phenylenediamine $(1.0 \mathrm{mmol})$ and aldehyde $(1.2 \mathrm{mmol})$ in methanol $(3 \mathrm{~mL})$ under open oxygen atmosphere, $10 \mathrm{~mol} \%$ of the solid Copper hydroxide catalyst were added. The resulting mixture was stirred at room temperature for appropriate time (Table 2). After completion of the reaction, as monitored by TLC, the reaction mixture was diluted with methanol $(20 \mathrm{~mL})$ and the catalyst was separated by filtration. The organic layer was concentrated under reduced pressure and the crude product was purified by silica gel column chromatography using ethyl acetate- $n$-hexane (1:9) as eluent to afford pure benzimidazole product. Some of the compounds spectral data are given below. 3a: 2-Phenyl-1H-benzimidazole (Tables 2, 3a): Solid, yield: 98\%, 0.190 g; m.p. $295^{\circ} \mathrm{C}-297^{\circ} \mathrm{C}$; IR (KBr): $v_{\max } 3039,2964,1460,1410$, 1309, 958, $708 \mathrm{~cm}^{-1} ;{ }^{1} \mathrm{H}$ NMR (400 MHz, DMSO-d 6 ): $\delta$ 7.17 - 7.23 (m, $2 \mathrm{H}) 7.44-7.54(\mathrm{~m}, 3 \mathrm{H}) 7.56-7.63(\mathrm{~m}$, $2 \mathrm{H}) 8.19(\mathrm{dd}, J=8.17,1.34 \mathrm{~Hz}, 2 \mathrm{H})$ ppm. 3l: 2-Pentyl-1H-benzimidazole (Table 2, 3I): Solid, yield: 80 $\%, 0.15$ g; m.p. $158^{\circ} \mathrm{C}-160^{\circ} \mathrm{C}$; IR (KBr): $v_{\max } 3049$, 2866, 2675, 1622, 1424, 1273, 1020, $750 \mathrm{~cm}^{-1}$; ${ }^{1} \mathrm{H}$ NMR (400 MHz, DMSO- $d 6): \delta 0.85\left(\mathrm{t}, J=6.95 \mathrm{~Hz}, 3 \mathrm{H}, \mathrm{CH}_{3}\right)$ 1.28 - $1.44\left(\mathrm{~m}, 4 \mathrm{H} \mathrm{CH}_{2}, 2 \mathrm{x}\right) 1.81-1.94\left(\mathrm{~m}, 2 \mathrm{H}, \mathrm{CH}_{2}\right)$ $2.93\left(\mathrm{t}, J=7.68 \mathrm{~Hz}, 2 \mathrm{H}, \mathrm{CH}_{2}\right) 7.21(\mathrm{dd}, J=5.85,3.17$ Hz, 2 H) 7.26 (s, 1 H) 7.55 (br. s., 1 H) 10.19 - 11.03 (m, $1 \mathrm{H}, \mathrm{NH}) \mathrm{ppm}$.

\section{REFERENCES}

[1] G. L. Gravatt, B. C. Baguley, W. R. Wilson and W. A. Denny, "DNA-Directed Alkylating Agents. 6. Synthesis and Antitumor Activity of DNA Minor Groove-Targeted Aniline Mustard Analogs of Pibenzimol (Hoechst 33258)," Journal of Medicinal Chemistry, Vol. 37, No. 25, 1994, pp. 4338-4345. http://dx.doi.org/10.1021/jm00051a010

[2] J. S. Kim, B. Gatto, C. Yu, A. Liu, L. F. Liu and J. Ed- 
mond LaVoie, "Substituted 2,5-Bi-1H-benzimidazoles: Topoisomerase I Inhibition and Cytotoxicity," Journal of Medicinal Chemistry, Vol. 39, No. 4, 1996, pp. 992-998. http://dx.doi.org/10.1021/jm950412w

[3] T. Roth, M. L. Morningstar, L. P. Boyer, H. S. Hughes, W. R. Buckheit Jr and J. C. Michejda, "Synthesis and Biological Activity of Novel Nonnucleoside Inhibitors of HIV-1 Reverse Transcriptase. 2-Aryl-Substituted Benzimidazoles," Journal of Medicinal Chemistry, Vol. 40, No. 26, 1997, pp. 4199-4207. http://dx.doi.org/10.1021/jm970096g

[4] D. A. Horton, G. T. Bourne and M. L. Smythe, "The Combinatorial Synthesis of Bicyclic Privileged Structures or Privileged Substructures," Chemical Reviews, Vol. 103, No. 3, 2003, pp. 893-930. http://dx.doi.org/10.1021/cr020033s

[5] B. Q. Gong, F. Hong, C. Kohm, L. Bonham and P. Klein, "Synthesis and SAR of 2-Arylbenzoxazoles, Benzothiazoles and Benzimidazoles as Inhibitors of Lysophosphatidic Acid Acyltransferase- $\beta$," Bioorganic \& Medicinal Chemistry Letters, Vol. 14, 2004, pp. 1455-1459. http://dx.doi.org/10.1016/j.bmcl.2004.01.023

[6] S. M. Sondhi, N. Singh, A. K. Lozach and L. Meijer, "Synthesis, Anti-Inflammatory, Analgesic and Kinase (CDK-1, CDK-5 and GSK-3) Inhibition Activity Evaluation of Benzimidazole/Benzoxazole Derivatives and Some Schiff's Bases," Bioorganic \& Medicinal Chemistry, Vol. 14, 2006, pp. 3758-3765.

http://dx.doi.org/10.1016/j.bmc.2006.01.054

[7] J. Vinsova, K. Cermakova, A. Tomeckova, M. Ceckova, J. Jampilek, P. Cermak, J. Kunes, M. Dolezal and F. Staud, "Synthesis and Antimicrobial Evaluation of New 2-Substituted 5,7-Di-tert-butylbenzoxazoles," Bioorganic \& Medicinal Chemistry, Vol. 14, No. 17, 2006, pp. 5850-5865. http://dx.doi.org/10.1016/j.bmc.2006.05.030

[8] J. M. Tebbe, A. W. Spitzer, F. Victor, C. S. Miller, C. C. Lee, R. T. Sattelberg, Sr E. McKinney and C. Joseph, "Antirhino/Enteroviral Vinylacetylene Benzimidazoles: A Study of Their Activity and Oral Plasma Levels in Mice," Journal of Medicinal Chemistry, Vol. 40, No. 24, 1997, pp. 3937-3947. http://dx.doi.org/10.1021/jm970423k

[9] R. Trivedi, K. Surya De and A. R. Gibbs, "A Convenient One-Pot Synthesis of 2-Substituted Benzimidazoles," Journal of Molecular Catalysis A, Vol. 245, No. 1-2, 2006, pp. 8-11. http://dx.doi.org/10.1016/j.molcata.2005.09.025

[10] Y. Bai, J. Lu, Z. Shi and B. Yang, "Synthesis of 2,15Hexadecanedione as a Precursor of Muscone," Synlett, Vol. 4, 2001, pp. 544-546.

[11] E. Hasegawa, A. Yoneoka, K. Suzuki, T. Kato, T. Kitazume and K. Yanagi, "Reductive Transformation of $\alpha, \beta$ Epoxy Ketones and Other Compounds Promoted through Photoinduced Electron Transfer Processes with 1,3-Dimethyl-2-phenylbenzimidazoline (DMPBI)," Tetrahedron, Vol. 55, 1999, pp. 12957-12968. http://dx.doi.org/10.1016/S0040-4020(99)00804-2

[12] M. R. Grimmet, "4.08-Imidazoles and Their Benzo Derivatives: (iii) Synthesis and Applications," In: A. R. Katritzky, C. W. Rees and K. T. Potts, Eds., Comprehen- sive Heterocyclic Chemistry, Pergamon Press, New York, Vol. 5, 1984, p. 457.

http://dx.doi.org/10.1016/B978-008096519-2.00076-X

[13] J. B. Wright, "The Chemistry of the Benzimidazoles," Chemical Reviews, Vol. 48, 1951, pp. 397-541. http://dx.doi.org/10.1021/cr60151a002

[14] R. W. Middleton and D. G. Wibberley, "Synthesis of Imidazo[4,5-b]- and [4,5-c]Pyridines," Journal of Heterocyclic Chemistry, Vol. 17, No. 8, 1980, pp. 1757-1760. http://dx.doi.org/10.1002/jhet.5570170824

[15] T. Hisano, M. Ichikawa, K. Tsumoto and M. Tasaki, "Synthesis of Benzoxazoles, Benzothiazoles and Benzimidazoles and Evaluation of Their Antifungal, Insecticidal and Herbicidal Activities," Chemical \& Pharmaceutical Bulletin, Vol. 30, 1982, p. 2996. http://dx.doi.org/10.1248/cpb.30.2996

[16] J. D. Geratz, F. M. Stevens, K. L. Polakoski and R. F. Parrish, "Amidino-Substituted Aromatic Heterocycles as Probes of the Specificity Pocket of Trypsin-Like Proteases," Archives of Biochemistry and Biophysics, Vol. 197, No. 2, 1979, pp. 551-559. http://dx.doi.org/10.1016/0003-9861(79)90279-0

[17] A. Czarny, W. D. Wilson and W. D. Boykin, "Synthesis of Mono-Cationic and Dicationic Analogs of Hoechst 33258," Journal of Heterocyclic Chemistry, Vol. 33, No. 4, 1996, pp. 1393-1397. http://dx.doi.org/10.1002/jhet.5570330463

[18] R. R. Tidwell, J. D. Geratz, O. Dann, G. D. Volz Zeh and H. Loew, "Diarylamidine Derivatives with One or Both of the Aryl Moieties Consisting of an Indole or IndoleLike Ring. Inhibitors of Arginine-Specific Esteroproteases," Journal of Medicinal Chemistry, Vol. 21, No. 7, 1978, pp. 613-623. http://dx.doi.org/10.1021/jm00205a005

[19] T. A. Fairley, R. R. Tidwell, I. Donkor, N. A. Naiman, K. A. Ohemeng, R. J. Lombardy, J. A. Bentley and M. Cory, "Structure, DNA Minor Groove Binding, and Base Pair Specificity of Alkyl- and Aryl-Linked Bis(amidinobenzimidazoles) and Bis(amidinoindoles)," Journal of Medicinal Chemistry, Vol. 36, No. 12, 1993, pp. 1746-1753. http://dx.doi.org/10.1021/jm00064a008

[20] K. Bougrin, A. Loupy and M. Soufiaoui, "Trois Nouvelles Voies de Synthèse des Dérivés 1,3-Azoliques sous Micro-Ondes," Tetrahedron, Vol. 54, No. 28, 1998, pp. 8055-8064. http://dx.doi.org/10.1016/S0040-4020(98)00431-1

[21] G. V. Reddy, V. V. V. N. S. Rama Rao, B. Narsaiah and P. S. Rao, "A Simple and Efficient Method for the Synthesis of Novel Trifluoromethyl Benzimidazoles under Microwave Irradiation Conditions," Synthetic Communications, Vol. 32, No. 16, 2002, pp. 2467-2476. http://dx.doi.org/10.1081/SCC-120003394

[22] A. Ben-Alloum, S. Bakkas and M. Soufiaoui, "Benzimidazoles Oxydation Hétérocyclisante par le Nitrobenzène ou le Diméthylsulfoxyde sur Silice et sous Irradiation Micro-Ondes ou Ultra-Violet," Tetrahedron Letters, Vol. 39, 1998, pp. 4481-4484. http://dx.doi.org/10.1016/S0040-4039(98)00868-5

[23] Y. Kawashita, N. Nakamichi, H. Kawabata and M. Ha- 
yashi, "Direct and Practical Synthesis of 2-Arylbenzoxazoles Promoted by Activated Carbon," Organic Letters, Vol. 5, No. 20, 2003, pp. 3713-3715. http://dx.doi.org/10.1021/o1035393w

[24] H. Sharghi, O. Asemani and R. Khalifeh, "New One-Pot Procedure for the Synthesis of 2-Substituted Benzimidazoles," Synthetic Communications, Vol. 38, No. 7, 2008, pp. 1128-1136. http://dx.doi.org/10.1080/00397910701863657

[25] W. R. Middleton and G. Wibberley, "Synthesis of Imidazo [4,5-b]- and [4,5-c] Pyridines," Journal of Heterocyclic Chemistry, Vol. 17, 1980, pp. 1757-1760. http://dx.doi.org/10.1002/jhet.5570170824

[26] F. F. Stephens and J. D. Bower, "The Preparation of Benziminazoles and Benzoxazoles from Schiff's Bases. Part I," Journal of the Chemical Society, 1949, pp. 2971-2972. http://dx.doi.org/10.1039/jr9490002971

[27] H. Chikashita, S. Nishida, M. Miyazaki, Y. Morita and K. Itoh, "In Situ Generation and Synthetic Application of 2-Phenylbenzimidazoline to the Selective Reduction of Carbon-Carbon Double Bonds of Electron-Deficient Olefins," Bulletin of the Chemical Society of Japan, Vol. 60, No. 2, 1987, p. 737. http://dx.doi.org/10.1246/bcsj.60.737

[28] S. Kumar, V. Kansal and A. Bhaduri, Indian Journal of Chemistry, Vol. 20, 1991, p. 254.

[29] F. Patzold, F. Zeuner, T. H. Heyer and H. Niclas, "Dehydrogenations Using Benzofuroxan as Oxidant," Synthetic Communications, Vol. 22, 1992, pp. 281-288. http://dx.doi.org/10.1080/00397919208021304

[30] L. R. Lombardy, A. F. Tanious, K. Ramachandra, R. R. Tidwell and W. D. Wilson, "Synthesis and DNA Interactions of Benzimidazole Dications Which Have Activity against Opportunistic Infections," Journal of Medicinal Chemistry, Vol. 39, No. 7, 1996, pp. 1452-1462. http://dx.doi.org/10.1021/jm9507946

[31] P. L. Beaulieu, B. Hache and E. V. Moos, "A Practical Oxone ${ }^{\mathbb{B}}$-Mediated, High-Throughput, Solution-Phase Synthesis of Benzimidazoles from 1,2-Phenylenediamines and Aldehydes and Its Application to Preparative Scale Synthesis,"Synthesis, Vol. 11, 2003, p. 1683. http://dx.doi.org/10.1055/s-2003-40888

[32] M. A. Chari, D. Shobha, S. M. J. Zaidi, B. V. S. Reddy and A. Vinu, "Nanoporous Aluminosilicate Catalyst with 3D Cage-Type Porous Structure as an Efficient Catalyst for the Synthesis of Benzimidazole Derivatives," Tetrahedron Letters, Vol. 51, No. 39, 2010, pp. 5195-5199. http://dx.doi.org/10.1016/j.tetlet.2010.07.132

[33] M. A. Chari, D. Shobha and T. Sasaki, "Room Temperature Synthesis of Benzimidazole Derivatives Using Reusable Cobalt Hydroxide and Cobalt Oxide as an Efficient Solid Catalysts," Tetrahedron Letters, Vol. 52, 2011, pp. 5575-5580. http://dx.doi.org/10.1016/j.tetlet.2011.08.047

[34] H. Jin, X. Xu, J. Gao, J. Zhong and Y. Wang, "Copper-Catalyzed One-Pot Synthesis of Substituted Benzimidazoles," Advanced Synthesis \& Catalysis, Vol. 352, No. 2-3, 2010, pp. 347-350. http://dx.doi.org/10.1002/adsc.200900706
[35] A. Dyer, "Zeolite Molecular Sieves," Wiley-VCH, Weinheim, 1988.

[36] C. T. Kresge, M. E. Leonowicz, W. J. Roth, J. C. Vartuli and J. S. Beck, "Ordered Mesoporous Molecular Sieves Synthesized by a Liquid-Crystal Template Mechanism," Nature, Vol. 359, 1992, p. 710.

http://dx.doi.org/10.1038/359710a0

[37] D. Zhao, Q. Huo, J. Feng, B. F. Chmelka and G. D. Stucky, "Nonionic Triblock and Star Diblock Copolymer and Oligomeric Surfactant Syntheses of Highly Ordered, Hydrothermally Stable, Mesoporous Silica Structures," Journal of the American Chemical Society, Vol. 120, No. 24, 1998, pp. 6024-6034.

http://dx.doi.org/10.1021/ja974025i

[38] D. Zhao, J. Feng, Q. Huo, N. Melosh, G. Fredrikson, B. F. Chmelka and G. D. Stucky, "Triblock Copolymer Syntheses of Mesoporous Silica with Periodic 50 to 300 Angstrom Pores," Science, Vol. 279, 1998, pp. 548-552. http://dx.doi.org/10.1126/science.279.5350.548

[39] A. Vinu, P. Srinivasu, M. Miyahara and K. Ariga, "Preparation and Catalytic Performances of Ultralarge-Pore TiSBA-15 Mesoporous Molecular Sieves with Very High Ti Content," Journal of Physical Chemistry B, Vol. 110, No. 2, 2006, pp. 801-806. http://dx.doi.org/10.1021/jp055851d

[40] A. Vinu, K. Z. Hossain, G. S. Kumar and K. Ariga, “Adsorption of 1-Histidine over Mesoporous Carbon Molecular Sieves," Carbon, Vol. 44, No. 3, 2006, pp. 530-536. http://dx.doi.org/10.1016/j.carbon.2005.08.004

[41] G. W. Breton, "Selective Monoacetylation of Unsymmetrical Diols Catalyzed by Silica Gel-Supported Sodium Hydrogen Sulfate," Journal of Organic Chemistry, Vol. 62, No. 25, 1997, pp. 8952-8954.

http://dx.doi.org/10.1021/j0971367y

[42] M. A. Chari and K. Syamasundar, "Polymer (PVP) Supported Ferric Chloride: An Efficient and Recyclable Heterogeneous Catalyst for High Yield Synthesis of 1,5Benzodiazepine Derivatives under Solvent Free Conditions and Microwave Irradiation," Catalysis Communications, Vol. 6, No. 1, 2005, pp. 67-70.

http://dx.doi.org/10.1016/j.catcom.2004.10.009

[43] J. Yang and T. Sasaki, "Synthesis of CoOOH Hierarchically Hollow Spheres by Nanorod Self-Assembly through Bubble Templating," Chemistry of Materials, Vol. 20, No. 5, 2008, p. 2049. http://dx.doi.org/10.1021/cm702868u

[44] J. Yang, H. Hyodo, K. Kimura and T. Sasaki, " $\mathrm{Co}(\mathrm{OH})_{3}$ Nanobelts: Synthesis, Characterization and Shape-Preserved Transformation to Pseudo-Single-Crystalline $\mathrm{Co}_{3} \mathrm{O}_{4}$ Nanobelts," Nanotechnology, Vol. 21, 2010, Article ID: 045605.

http://dx.doi.org/10.1088/0957-4484/21/4/045605

[45] J. Yang and T. Sasaki, "Morphological Control of Single Crystalline $\mathrm{Co}_{3} \mathrm{O}_{4}$ Polyhedrons: Selective and Nonselective Growth of Crystal Planes Directed by Differently Charged Surfactants and Solvents," Crystal Growth \& Design, Vol. 10, No. 3, 2010, pp. 1233-1236. http://dx.doi.org/10.1021/cg9012284

[46] M. A. Chari, D. Shobha and T. Sasaki, "Room Temperature Synthesis of Benzimidazole Derivatives Using Re- 
usable Cobalt Hydroxide (II) and Cobalt Oxide (II) as Efficient Solid Catalysts," Tetrahedron Letters, Vol. 52, No. 43, 2011, pp. 5575-5580. http://dx.doi.org/10.1016/j.tetlet.2011.08.047

[47] J. Smith and I. Ho "Organic Redox Reactions during the Interaction of $o$-Phenylenediamine with Benzaldehyde," Tetrahedron Letters, Vol. 12, No. 38, 1971, pp. 3541-
3544. http://dx.doi.org/10.1016/S0040-4039(01)97226-0

[48] A. T. Khan, T. Parvin and L. H. Choudhury, "A Simple and Convenient One-Pot Synthesis of Benzimidazole Derivatives Using Cobalt (II) Chloride Hexahydrate as Catalyst," Synthetic Communications, Vol. 39, No. 13, 2009, pp. 2339-2346. 